\title{
In Vitro Regeneration of Triploid Plants of Euonymus alatus 'Compactus' (Burning Bush) from Endosperm Tissues
}

\author{
Chandra Thammina ${ }^{2}$, Mingyang $\mathrm{He}^{1,2}$, Litang $\mathrm{Lu}^{1,2}$, Kaishuang Cao, \\ and Hao Yu \\ Department of Plant Science and Landscape Architecture, University of \\ Connecticut, 105 Ahern Lane, Storrs, CT 06269
}

Yongqin Chen ${ }^{1}$ and Liangtao Tian

College of Life Sciences, Hubei University, Wuhan 430062, China

Junmei Chen, Richard McAvoy, and Donna Ellis

Department of Plant Science and Landscape Architecture, University of Connecticut, 105 Ahern Lane, Storrs, CT 06269

\section{Degang Zhao \\ Guizhou Key Laboratory of Agricultural Bioengineering, Guizhou University, Guiyang 550025, China}

Yuejin Wang and Xian Zhang

College of Horticulture, Northwest Sci-Tech University of Agriculture and Forestry, Yangling 712100, China

\section{$\mathbf{Y i} \mathbf{L i}^{3}$}

Department of Plant Science and Landscape Architecture, University of Connecticut, 105 Ahern Lane, Storrs, CT 06269

Additional index words. invasive ornamental plants, winged euonymus, sterility, flow cytometry, ploidy

\begin{abstract}
Euonymus alatus (Thunb.) Sieb., commonly known as "burning bush," is an extremely popular landscape plant in the United States as a result of its brilliant showy red leaves in fall. However, $E$. alatus is also seriously invasive because of its prolific seed production and effective seed dispersal by birds. Thus, development of sterile, noninvasive, seedless triploid $E$. alatus is in high demand. In this article, we report successful production of triploid $E$. alatus using endosperm tissues as explants. In our study, $\approx \mathbf{5 0} \%$ of immature endosperm explants and $14 \%$ of mature endosperm explants formed compact, green calli after culture in the dark for 8 weeks and then under light for 4 weeks on Murashige and Skoog (MS) medium supplemented with $2.2 \mu \mathrm{M}$ BA and $2.7 \mu \mathrm{M}$ $\alpha$-naphthaleneacetic acid (NAA). Approximately 5.6\% of the immature endospermderived calli and $13.4 \%$ of mature endosperm-derived calli initiated shoots within 8 weeks after they were cultured on MS medium with $4.4 \mu M$ benzyladenine (BA) and 0.5 $\mu M$ indole-3-butyric acid (IBA). Eighty-five percent of shoots rooted after culture on woody plant medium (WPM) containing $4.9 \mu$ M IBA for 2 weeks and then on hormonefree WPM medium containing $2.0 \mathrm{~g} \cdot \mathrm{L}^{-1}$ activated charcoal for 4 weeks. Eight independently regenerated triploid plants have been identified. Triploid plant regeneration rates observed were $0.42 \%$ from immature endosperm explants and $0.34 \%$ from mature endosperm explants, respectively, based on the number of endosperm explants cultured. Because triploid plants cannot produce viable seeds, and thus are sterile and non-invasive, some triploid $E$. alatus plant lines reported here can be used to replace the currently used invasive counterparts. Chemical names used: benzyladenine (BA), indole-3-butyric acid (IBA), and $\alpha$-naphthaleneacetic acid (NAA).
\end{abstract}

Euonymus alatus (Thunb.) Sieb. is a deciduous shrub belonging to the family of Celastraceae. It was introduced into the United States from northeastern/central China in 1860 (Chen et al., 2006; Dirr, 1998) for horticultural purposes. E. alatus is considered one of the great aesthetic and highly adaptable shrubs for the American gardeners (Dirr, 1998).
Because of its brilliant red fall leaf color, it is commonly referred as "burning bush." As a result of its huge economical value and popularity, E. alatus has been extensively sold by nurseries, contributing significantly to the $\$ 16$ billion U.S. ornamental horticulture industry (U.S. Department of Agriculture, 2005a). There are various cultivars of E. alatus avail- able in the United States like 'Kosho Mayune', 'Odom', 'Pipzam', 'Compactus', 'Rudy Haag', and 'Timber Creek', but 'Compactus' is the most widely used one because of its compact form and rounded shape. In Connecticut, annual sales of E. alatus 'Compactus' reached more than $\$ 5$ million (Heffernan, 2005).

E. alatus can survive in a wide range of soils and environmental conditions. A mature E. alatus plant produces tens of thousands of viable seeds a year. Birds and rainwater readily disperse those seeds to long distances, leading to the establishment of E. alatus plants in a variety of habitats. Once the plant is established, it can form dense thickets that displace native vegetation, posing a threat to the plant biodiversity (USDA, NRCS, 2005b). E. alatus has been reported to be invasive in 21 states in the U.S. (Ding et al., 2006). Many states intend to ban the sale, planting, and propagation of E. alatus because of its invasiveness. However, as a result of the economic importance of E. alatus to the ornamental and landscape industries and its popularity among consumers, development of sterile, non-invasive E. alatus cultivars is in high demand (Gagliardi and Brand, 2007).

The invasiveness of E. alatus is related to its high seed production but sterility will eliminate the problem (Li et al., 2004). Sterile plants can be produced through conventional methods or by gene transfer approaches (Li et al., 2004). Although there are several methods available to produce sterile plants through gene transfer approaches (Chen et al., 2006, 2008; Li et al., 2004; Zheng et al., 2007), the use of transgenic sterile ornamental plants may be limited ( $\mathrm{Li}$ and Duan, 2011). This is partially because of concerns over transgenic plants although some gene confinement technologies have been developed (Hong et al., 2009; Kausch et al., 2010; Li and Duan, 2011; Luo et al., 2007). At present, using non-transgenic sterile ornamental plants created by conventional procedures is much more desirable. One such procedure is to produce triploids, because triploid plants are sterile as a result of uneven chromosome division during meiosis (Ramsey and Schemske, 1998).

Traditionally, triploids are produced by hybridization between tetraploids and diploids. That approach is time-consuming and technically difficult, especially for some woody species. Endosperm in angiosperms is naturally triploid and in vitro culture of endosperm explants has been used as a method for producing triploid plants, although regeneration from endosperm tissues is often technically challenging (Thomas and Chaturvedi, 2008). In this article, we report for the first time in vitro regeneration of triploid plants from immature and mature endosperm explants of E. alatus 'Compactus'. Successful development of triploid lines of E. alatus 'Compactus' provides a foundation to use sterile, noninvasive cultivars to replace the invasive counterparts. 


\section{Materials and Methods}

Plant material. Immature fruits and mature fruits were collected in the first week of September and third week of November, respectively, from 10-year-old plants of E. alatus 'Compactus' grown in the Prides Corner Farms, Lebanon, CT.

Culture media and conditions. Except for rooting, all the media described here were comprised of MS salts (Murashige and Skoog, 1962 ) with $100 \mathrm{mg} \cdot \mathrm{L}^{-1}$ myo-inositol, $2.0 \mathrm{mg} \cdot \mathrm{L}^{-1}$ glycine, $1.0 \mathrm{mg} \cdot \mathrm{L}^{-1}$ thiamine- $\mathrm{HCl}, 0.5 \mathrm{mg} \cdot \mathrm{L}^{-1}$ nicotinic acid, $0.5 \mathrm{mg} \cdot \mathrm{L}^{-1}$ pyridoxine $-\mathrm{HCl}$, $0.3 \mathrm{~g} \cdot \mathrm{L}^{-1}$ casein hydrolysate, $0.5 \mathrm{~g} \cdot \mathrm{L}^{-1} 2-(N-$ morpholino) ethanesulfonic acid, $30.0 \mathrm{~g} \cdot \mathrm{L}^{-1}$ sucrose, and $7.0 \mathrm{~g} \cdot \mathrm{L}^{-1}$ agar. The $\mathrm{pH}$ of all culture media was adjusted to 5.8 with $\mathrm{KOH}$ or $\mathrm{HCl}$ before addition of agar. All media were autoclaved at $121^{\circ} \mathrm{C}$ for $20 \mathrm{~min}$, and all the cultures, except for those specifically mentioned, were maintained at $23 \pm 2{ }^{\circ} \mathrm{C}$ under 35 to $45 \mu \mathrm{mol} \cdot \mathrm{m}^{-2} \cdot \mathrm{s}^{-1}$ light provided by white cool fluorescent tube lamps over a 16-h photoperiod.

Callus and shoot induction from immature endosperm explants. Immature fruits of $E$. alatus 'Compactus' were thoroughly washed with running tap water for $30 \mathrm{~min}$. The fruits were then surface-sterilized by immersion in $0.6 \%$ solution of sodium hypochlorite containing $0.1 \%$ Tween 20 (Sigma, St. Louis, MO) for $30 \mathrm{~min}$ and rinsed three times with sterile distilled water. The fruits were then soaked in $75 \%(\mathrm{v} / \mathrm{v})$ ethanol and swirled for 2 min. After washing three times in sterile distilled water, immature seeds were isolated from the fruits. Seed coats and embryos were removed and the immature endosperm explants were cultured in disposable petri dishes $(90 \times 20 \mathrm{~mm})$ containing MS medium supplemented with different combinations of four concentrations of BA $(2.22,4.44,8.88$, and $17.76 \mu \mathrm{M})$, three concentrations of NAA $(2.69,5.38$, and $10.76 \mu \mathrm{M})$, and two concentrations of 2, 4-dichlorophenoxy-acetic acid (2,4-D) $(2.26$ and $9.04 \mu \mathrm{M})$ to induce callus. Immature endosperm explants were also cultured on hormone-free MS medium as control. Thirty endosperm explants were cultured for each replicate at 10 explants per petri dish, and each treatment had three replicates. Explants

Received for publication 18 Apr. 2011. Accepted for publication 23 June 2011.

We appreciate the financial support from New England Invasive Plant Center, USDA NIFA, UConn College of Agricultural and Natural Resources, and Storrs Agriculture Experiment Station to The Li Laboratory for this project. We thank Dr. Carol Norris, Biotechnology-Bioservices Center, University of Connecticut, Storrs, CT, for her help in flow cytometry analysis.

${ }^{1}$ These authors are/were Ph.D. interns from China and cosupervised by $\mathrm{Yi} \mathrm{Li}$ and their home institution advisors in China, their advisors in China, and are therefore coauthors of this article.

${ }^{2}$ These authors contributed equally and are considered cofirst authors.

${ }^{3}$ To whom reprint requests should be addressed; e-mail yi.li@uconn.edu. were cultured initially in the dark for 8 weeks and then under light (15 to $\left.20 \mu \mathrm{mol} \cdot \mathrm{m}^{-2} \cdot \mathrm{s}^{-1}\right)$ for another 4 weeks. The cultures were transferred to fresh media every 2 weeks. Callus formation data were recorded at Week 12 of culture and mean number of immature endosperm explants forming calli was calculated based on three replicates for each treatment. Callus induction rate was calculated by dividing the number of explants forming calli by the number of immature endosperm explants cultured. Mean callus induction rate was based on three replicates for each treatment. After 12 weeks of culture, compact, greenish calli formed on six callus induction media supplemented with $2.22,4.44$, or 8.88 $\mu \mathrm{M}$ BA and 2.69 or $5.38 \mu \mathrm{M}$ NAA were cut into pieces $(\approx 0.5 \mathrm{~cm} \times 0.5 \mathrm{~cm}$ in size $)$ and transferred to the petri dishes containing shoot induction media supplemented with 4.44 or $13.32 \mu \mathrm{M}$ BA, 9.13 or $18.26 \mu \mathrm{M}$ zeatin, and 9.30 or $18.60 \mu \mathrm{M}$ kinetin plus $0.49 \mu \mathrm{M}$ IBA or $0.57 \mu \mathrm{M}$ indole-3-acetic acid (IAA). Callus segments were also cultured on hormonefree MS medium as control. Fifty callus tissues were cultured for each replicate with 10 segments per petri dish. Each treatment had three replicates. All the cultures were transferred onto fresh media every 2 weeks and the bud induction lasted for 8 weeks. Bud (shoot bud) formation was recorded at Week 8 of culture. Bud induction rates were calculated by dividing the number of calli forming shoot buds by the number of calli cultured.

After the best media for callus and shoot induction were identified, a large number of immature endosperm explants was isolated from E. alatus 'Compactus' fruits and cultured on the MS medium containing $2.22 \mu \mathrm{M}$ $\mathrm{BA}$ and $2.69 \mu \mathrm{M}$ NAA for callus formation. Compact, green calli produced were then transferred onto the MS medium containing $4.44 \mu \mathrm{M}$ BA and $0.49 \mu \mathrm{M}$ IBA for shoot induction. Meanwhile, 100 immature embryos were also isolated and cultured on MS medium substituted with $2.22 \mu \mathrm{M}$ BA and 2.69 $\mu \mathrm{M}$ NAA to produce calli. At Week 12 of culture, embryos forming calli were transferred to the MS medium containing $4.44 \mu \mathrm{M}$ $\mathrm{BA}$ and $0.49 \mu \mathrm{M}$ IBA for shoot induction. Callus induction rates were calculated based on the number of embryo/endosperm explants forming calli (observed at Week 12) divided by the number of embryo/endosperm explants cultured. Data on shoot formation were collected at Week 8 of culture. Shoot induction rates were calculated by dividing the number of calli that developed shoot buds by the number of calli cultured.

Callus and shoot induction from mature endosperm explants. In the third week of November, mature fruits were harvested and seeds were isolated from the fruits, washed with tap water thoroughly, and then surfacedisinfected by submerging them in a solution of $1.2 \%$ sodium hypochlorite containing $0.1 \%$ Tween 20 for 10 min followed by washing three times with sterile distilled water. Then, the seeds were further sterilized with a $0.6 \%$ solution of sodium hypochlorite containing $0.1 \%$ Tween 20 for $30 \mathrm{~min}$ followed by rinsing with sterile distilled water five times. We sterilized mature seeds twice with sodium hypochlorite solution to minimize microbial contamination. After sodium hypochlorite sterilization and water rinsing, the seeds were soaked in $75 \%(\mathrm{v} / \mathrm{v})$ ethanol for $5 \mathrm{~min}$ and washed five times with sterile water. Then they were transferred onto the MS medium (with $7.0 \mathrm{~g} \cdot \mathrm{L}^{-1}$ agar), containing $100 \mu \mathrm{l} \cdot \mathrm{L}^{-1}$ Proclin 300 (Supelco, Bellefonte, PA), a preservative used in tissue culture media for the control of microorganism growth (Nagy et al., 2005). Our observation was that Proclin 300 worked well to minimize bacterial or fungal contaminations. The seeds were maintained on the MS medium at 10 seeds per petri dish at $23{ }^{\circ} \mathrm{C}$ under light with a 16 -h photoperiod for 1 month and then in the dark at $4{ }^{\circ} \mathrm{C}$ for 3 months for two reasons. One is that individual contaminated seeds could be easily identified and removed during the first month culture. The another reason is that a prolonged incubation (additional 3 months) of seeds on MS medium made seedcoats soft and therefore could be removed when we isolated endosperm tissues. At the end of 4 months, seedcoats and embryo tissues were carefully removed and mature endosperm tissues were isolated and cultured on MS medium supplemented with $2.22 \mu \mathrm{M}$ BA and $2.69 \mu \mathrm{M}$ NAA to produce calli. Approximately 585 mature endosperm explants were cultured at 10 to 15 explants per petri dish. Culture conditions were same as those used for immature endosperm explants. At Week 12 of culture, observations were taken on callus induction and compact greenish calli of $\approx 0.75 \mathrm{~cm} \times 0.75$ $\mathrm{cm}$ in size were transferred to the MS medium containing $4.44 \mu \mathrm{M}$ BA and $0.49 \mu \mathrm{M}$ IBA for shoot induction. Approximately 10 calli were cultured per petri dish. Shoot formation results were recorded at Week 8 of culture on the shoot induction medium. All the cultures were transferred to fresh media every 2 to 3 weeks.

Rooting and bud dormancy breaking. After shoot buds were formed from embryoor endosperm-derived calli, they were transferred together with their callus explants into Magenta boxes containing the MS medium supplemented with $4.44 \mu \mathrm{M} \mathrm{BA}$ and $0.49 \mu \mathrm{M}$ IBA for further growth. When the shoots grew to 1 to $2 \mathrm{~cm}$ in height, they were excised from callus tissues and cultured on root induction Medium I, which comprised halfstrength WPM (Lloyd and McCown, 1980) with $2 \%$ sucrose, $0.04 \%$ ammonium nitrate, $0.4 \%$ agar, $0.14 \%$ phytagel (a blended agar and phytagel medium was used to produce a totally transparent medium so that initiation and growth of roots could be easily monitored), and 4.9 $\mu \mathrm{M}$ IBA (Clements, 2007). Two weeks later, the shoots were transferred onto rooting Medium II (Clements, 2007), which was IBA-free rooting Medium I with $2 \mathrm{~g} \cdot \mathrm{L}^{-1}$ activated charcoal (Kang et al., 2009). The $\mathrm{pH}$ of the rooting media was adjusted to 5.2 with $\mathrm{KOH}$ or $\mathrm{HCl}$ before the addition of gelling agents. Because all rooted plants became dormant after 3 to 6 weeks of culture, they were transferred to a $4{ }^{\circ} \mathrm{C}$ incubator and 
maintained there for 3 months in the dark to break bud dormancy. After the cold treatment, the plants were transferred to a culture room to resume active growth.

Determination of ploidy. Flow cytometry was used to determine the ploidy level of the endosperm-derived E. alatus 'Compactus' plants. Ploidy determination was based on the total DNA content per nucleus measured with a CyFlow Ploidy Analyser (Partec GmbH, Münster, Germany) using 4',6-diamidino-2phenylindole (DAPI). Nuclei were extracted using the Partec Cystain PI absolute P kit according to the manufacturer's instructions. Approximately $0.5 \mathrm{~cm} \times 0.5-\mathrm{cm}$ young leaves of the embryo- or endosperm-derived plants were chopped with a sharp razor blade in a 55 -mm-diameter petri dish containing $500 \mu \mathrm{L}$ nuclei extraction buffer. The extracts were filtered through a Partec $30 \mu \mathrm{m}$ CellTrics disposable filter and stained with $2 \mathrm{~mL}$ staining buffer containing DAPI. The young leaves from embryo-derived plants were used as diploid controls (2C). Triploids (3C) were identified by comparing their linear fluorescence intensity (the DNA content per nucleus) with that of the diploid controls (2C). If an endosperm-derived plant had 50\% more DNA per nucleus than that of embryo-derived plant (2C), the plant was considered a triploid.

To eliminate experimental variations in determining the ploidy level (the DNA content per nucleus) among different plant samples, we also used diploid leaf tissues of $E$. alatus 'Compactus' as an internal standard. Leaf disks from a diploid plant and each triploid plant were mixed and chopped together to prepare nuclei. The nuclei mixture was further analyzed with flow cytometry. If the histogram had two distinct peaks with a ratio of $1: 1.5$ in the DNA content per nucleus, the triploid plant was verified.

We further confirmed the ploidy level of the identified triploid plants using a different flow cytometer, FACS Calibur Dual Laser Flow Cytometer (B.D. Immunocytometry Systems, San Jose, CA), and a different DNA stain, propidium iodide (PI), to quantify the DNA content per nucleus. Furthermore, to reduce experimental variations in ploidy level determination, leaf disks from a diploid plant were also mixed with leaf disks from each independent triploid line before nuclei were isolated. Again, if two distinct peaks with a ratio of 1:1.5 in the DNA content per nucleus were observed in the mixture, the triploidy was confirmed.

The ploidy level of each triploid plant derived from endosperm tissues was determined and verified at least three times based on the mentioned procedures with leaves harvested at different growth stages. Data presented in this article were collected from a FACS Calibur Dual Laser Flow Cytometer with PI as the DNA stain. Triploid plant induction rates were derived by dividing the number of independent triploid plants regenerated by the number of endosperm explants cultured.

Plant acclimatization. Both triploid and diploid plants were acclimatized by gradual lid opening of Magenta boxes in $3 \mathrm{~d}$ before they were taken out of the boxes. Plants were gently washed under tap water to remove gelling agents and they were then transplanted to 2-inch diameter pots with Promix potting soil (Premier Horticulture Inc.; PA). The potted plants were acclimatized for 3 to 4 weeks at room temperature and subsequently transferred to a greenhouse for further growth.

Data analysis. Data on callus and shoot bud induction were analyzed with Duncan's multiple range test at $P \leq 0.05$ using SPSS 19.0 Software (IBM Corporation, Somers, NY).

\section{Results}

Callus and shoot induction from endosperm explants. Endosperm tissues with seedcoats and embryos completely removed were used for triploid callus induction (Fig. 1A). Plant growth regulators were essential for the immature endosperm of E. alatus to form callus. Callus was not induced on the explants cultured on hormone-free MS medium within 12 weeks of culture (Table 1). Callus formation was observed on the surfaces of some explants after 2 to 3 weeks of culture on the medium containing BA and NAA or 6 weeks of culture on the medium containing BA and 2,4-D. All calli were white or cream in color and loose when cultured in dark, but those on NAA-containing media gradually turned green and compact after being transferred to light (Fig. 1B). Within 12 weeks of culture, significant differences in callus induction were observed among some media (Table 1). 2,4$D$ was less effective in callus induction than NAA when used in combination with the same concentration of BA (Table 1). In addition, calli induced on 2,4-D-supplemented media were yellowish and loose even when they were maintained under light. The highest callus induction rate $(51 \%)$ was observed on the medium supplemented with $2.22 \mu \mathrm{M}$ BA plus $2.69 \mu$ M NAA (Table 1).

To induce bud formation, compact, green calli were cut into pieces and placed on a MS medium supplemented with different cytokinins (BA, zeatin, or kinetin) and auxins (IBA or IAA) at various concentrations. All
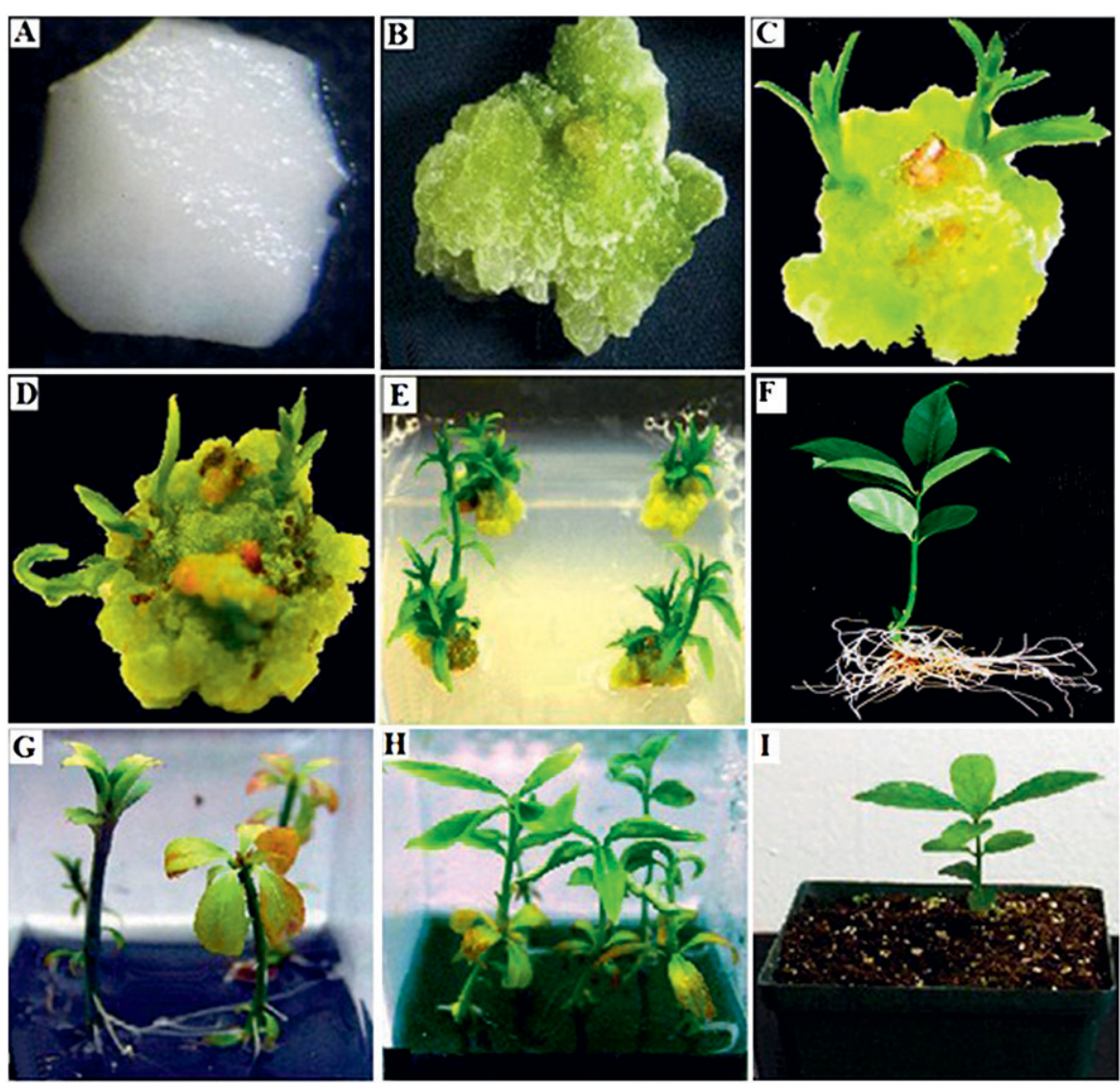

Fig. 1. Triploid plant regeneration from endosperm tissues of Euonymus alatus 'Compactus'. (A) An immature endosperm explant isolated from immature fruit; (B) green callus developed from an immature endosperm explant that was cultured initially in dark and then under light on a MS medium with $2.22 \mu \mathrm{M}$ BA and 2.69 $\mu \mathrm{M}$ NAA; (C) an immature endosperm-derived callus forming adventitious buds on a MS medium with $4.44 \mu \mathrm{M}$ BA and $0.49 \mu \mathrm{M}$ IBA; (D) a mature endosperm-derived callus forming buds on a MS medium with $4.44 \mu \mathrm{M}$ BA and $0.49 \mu \mathrm{M}$ IBA; (E) shoots developed from immature endosperm-derived calli; (F) a rooted triploid plant regenerated from an immature endosperm-derived callus; (G) endosperm regenerated plants entering dormancy. Note yellow or red color leaves, inactive shoot apical and lateral buds; $(\mathbf{H})$ new flush of growth observed on the plants that were cold treated at $4{ }^{\circ} \mathrm{C}$ for 3 months and then cultured at room temperature for $50 \mathrm{~d}$; (I) an acclimatized triploid plant growing in a pot containing Promix soil in the greenhouse. MS $=$ Murashige and Skoog; BA = benzyladenine; NAA $=\alpha$-naphthaleneacetic acid; IBA $=$ indole-3-butyric acid. 
calli grew well after subculture, enlarging in size and remaining green in color, but most of them did not produce buds for up to 8 weeks after induction. Bud formation was observed only on the MS medium containing 4.44 or $13.32 \mu \mathrm{M}$ BA plus $0.49 \mu \mathrm{M}$ IBA (Table 2). A small number of calli produced adventitious buds after 3 to 4 weeks of subculture (Fig. 1C). There was no significant difference in bud induction rates between the two BA treatments (Table 2). Buds further developed into 1 - to 2 -cm long shoots during subsequent culture in Magenta boxes (Fig. $1 \mathrm{E})$. However, the number of callus explants forming buds did not increase with the culture time. Both zeatin (at 9.13 or $18.26 \mu \mathrm{M}$ ) and kinetin (at 9.30 or $18.60 \mu \mathrm{M}$ ) failed to induce bud formation in the presence of 0.49 $\mu \mathrm{M}$ IBA.

Table 1. The effect of auxins (NAA, 2,4-D) and cytokinin (BA) concentrations on callus formation from immature endosperm explants of Euonymus alatus 'Compactus'. ${ }^{2}$

\begin{tabular}{|c|c|c|c|c|c|}
\hline \multicolumn{3}{|c|}{ Concn of growth regulator $(\mu \mathrm{M})$} & \multirow{2}{*}{$\begin{array}{l}\text { Number of } \\
\text { explants forming } \\
\text { calli }(\text { mean } \pm \mathrm{SE})^{\mathrm{y}}\end{array}$} & \multirow{2}{*}{$\begin{array}{l}\text { Mean callus } \\
\text { induction rate } \\
(\% \pm \mathrm{SE})^{\mathrm{x}}\end{array}$} & \multirow{2}{*}{$\begin{array}{c}\text { Callus } \\
\text { characteristics }\end{array}$} \\
\hline BA & NAA & $2,4-\mathrm{D}$ & & & \\
\hline 0 & 0 & 0 & $0 \pm 0$ & $0 \pm 0 \mathrm{j}^{\mathrm{w}}$ & NA \\
\hline 2.22 & 2.69 & - & $15.3 \pm 1.2$ & $51.1 \pm 4.0 \mathrm{a}$ & Compact and greenish \\
\hline 4.44 & 2.69 & - & $12.0 \pm 1.0$ & $40.0 \pm 3.3 \mathrm{~b}$ & Compact and greenish \\
\hline 8.88 & 2.69 & - & $9.7 \pm 0.7$ & $32.2 \pm 2.2 \mathrm{c}$ & Compact and greenish \\
\hline 17.76 & 2.69 & - & $3.3 \pm 0.9$ & $11.1 \pm 2.9 \mathrm{fghi}$ & Compact and greenish \\
\hline 2.22 & 5.38 & - & $9.0 \pm 1.1$ & $30.0 \pm 3.8 \mathrm{c}$ & Compact and greenish \\
\hline 4.44 & 5.38 & - & $6.3 \pm 0.7$ & $21.1 \pm 2.2 \mathrm{de}$ & Compact and greenish \\
\hline 8.88 & 5.38 & - & $5.3 \pm 0.3$ & $17.8 \pm 1.1 \mathrm{def}$ & Compact and greenish \\
\hline 17.76 & 5.38 & - & $4.3 \pm 0.3$ & $14.4 \pm 1.1 \mathrm{efgh}$ & Compact and greenish \\
\hline 2.22 & 10.76 & - & $6.7 \pm 0.3$ & $22.2 \pm 1.1 \mathrm{~d}$ & Compact and greenish \\
\hline 4.44 & 10.76 & - & $5.7 \pm 0.7$ & $18.9 \pm 2.2 \mathrm{de}$ & Compact and greenish \\
\hline 8.88 & 10.76 & - & $5.3 \pm 0.7$ & $17.8 \pm 2.2 \mathrm{def}$ & Compact and greenish \\
\hline 17.76 & 10.76 & - & $2.7 \pm 0.3$ & $8.9 \pm 1.1 \mathrm{ghi}$ & Compact and greenish \\
\hline 4.44 & - & 2.26 & $5.7 \pm 0.3$ & $18.9 \pm 1.1 \mathrm{de}$ & Loose and yellowish \\
\hline 4.44 & - & 9.04 & $4.7 \pm 0.7$ & $15.5 \pm 2.2 \mathrm{defg}$ & Loose and yellowish \\
\hline 17.76 & - & 2.26 & $2.3 \pm 0.3$ & $7.8 \pm 1.1 \mathrm{hi}$ & Loose and yellowish \\
\hline 17.76 & - & 9.04 & $1.3 \pm 0.3$ & $4.4 \pm 1.1 \mathrm{i}$ & Loose and yellowish \\
\hline
\end{tabular}

${ }^{\mathrm{z}}$ Each treatment had three replicates with 30 immature endosperm explants per replicate.

${ }^{y}$ Callus formation was recorded at Week 12 of culture. Mean number of immature endosperm explants forming calli was derived from three replicates for each treatment.

${ }^{\mathrm{x}}$ Callus induction rate was calculated by dividing the number of explants forming calli by the number of immature endosperm explants cultured.

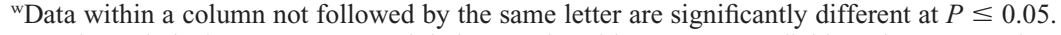

$\mathrm{BA}=$ benzyladenine; NAA $=\alpha$-naphthaleneacetic acid; 2,4-D = 2, 4-dichlorophenoxy-acetic acid.; NA = not applicable because no callus was induced.

Table 2. The effect of auxins (IAA, IBA) and cytokinins (BA, zeatin, and kinetin) concentrations on regeneration of shoot buds from calli derived from Euonymus alatus 'Compactus' immature endosperm explants. ${ }^{2}$

\begin{tabular}{|c|c|c|c|c|c|c|}
\hline \multicolumn{5}{|c|}{ Concn of growth regulator $(\mu \mathrm{M})$} & \multirow{2}{*}{$\begin{array}{l}\text { Number of } \\
\text { calli forming shoot } \\
\text { buds }(\text { mean } \pm \mathrm{SE})^{\mathrm{y}}\end{array}$} & \multirow{2}{*}{$\begin{array}{l}\text { Mean shoot } \\
\text { bud induction } \\
\text { rate }(\% \pm \mathrm{SE})^{\mathrm{x}}\end{array}$} \\
\hline BA & Zeatin & Kinetin & IAA & IBA & & \\
\hline 0 & 0 & 0 & 0 & 0 & $0 \pm 0$ & $0 \pm 0 \mathrm{~b}^{\mathrm{w}}$ \\
\hline 4.44 & - & - & - & 0.49 & $2.7 \pm 0.3$ & $5.3 \pm 0.7 \mathrm{a}$ \\
\hline 13.32 & - & - & - & 0.49 & $3.0 \pm 1.0$ & $6.0 \pm 2.0 \mathrm{a}$ \\
\hline 4.44 & - & - & 0.57 & - & $0 \pm 0$ & $0 \pm 0 \mathrm{~b}$ \\
\hline 13.32 & - & - & 0.57 & - & $0 \pm 0$ & $0 \pm 0 \mathrm{~b}$ \\
\hline- & 9.13 & - & - & 0.49 & $0 \pm 0$ & $0 \pm 0 \mathrm{~b}$ \\
\hline - & 18.26 & - & - & 0.49 & $0 \pm 0$ & $0 \pm 0 \mathrm{~b}$ \\
\hline - & - & 9.30 & - & 0.49 & $0 \pm 0$ & $0 \pm 0 \mathrm{~b}$ \\
\hline - & - & 18.60 & - & 0.49 & $0 \pm 0$ & $0 \pm 0 \mathrm{~b}$ \\
\hline
\end{tabular}

${ }^{\mathrm{z}}$ Each treatment had three replicates with 50 calli per replicate.

${ }^{\mathrm{y}} \mathrm{Bud}$ formation was recorded at Week 8 of culture. Mean number of calli forming shoot buds was based on three replicates for each treatment.

${ }^{\mathrm{x}}$ Shoot bud induction rate was calculated by dividing the number of calli forming shoot buds by the number of calli cultured.

${ }^{\text {w } D a t a}$ within a column not followed by the same letter are significantly different at $P \leq 0.05$.

$\mathrm{BA}$ = benzyladenine; IBA = indole-3-butyric acid; IAA = indole-3-acetic acid. ferred to bud induction medium (MS with $4.44 \mu \mathrm{M}$ BA and $0.49 \mu \mathrm{M}$ IBA), 11 of 82 mature endosperm-derived calli initiated buds within 8 weeks (Fig. 1D; Table 3).

Plant regeneration and breaking dormancy. Shoots longer than $1 \mathrm{~cm}$ were excised from the calli and cultured on root induction medium I (half-strength WPM with $4.9 \mu \mathrm{M}$ IBA). Two weeks later, shoots were transferred onto root induction Medium II (auxin-free halfstrength WPM containing $2.0 \mathrm{~g} \cdot \mathrm{L}^{-1}$ activated charcoal). The root cultures were transferred to fresh medium every 4 weeks. We have observed that adventitious roots initiated from the base of the shoots 4 weeks after transfer, and $85 \%$ of the shoots developed into healthy plants with well-developed roots within 10 weeks of culture (Fig. 1F).

After 2 months of culture on the rooting Medium II, the apical and lateral buds became dormant. Growth stopped and the leaves turned yellow to red in color (Fig. 1G). To break bud dormancy, the plants were transferred to a $4{ }^{\circ} \mathrm{C}$ incubator and maintained there for 3 months. The root cultures were transferred to fresh root induction Medium II every 4 weeks. After the cold treatment, plants were moved to a culture room and 2 weeks later they started new growth. The newly growing plants generally reached 3 to $6 \mathrm{~cm}$ in height after 2 months (Fig. 1H).

Ploidy determination and triploid identification. We identified triploid lines from endosperm-derived plants using flow cytometry techniques. We initially compared ploidy levels of individual plants derived from diploid embryo tissues with those from endosperm tissues, which can be diploid, triploid, or tetraploid, using the Partec CyFlow Ploidy Analyser with DAPI as a fluorescent DNA stain. Once we identified triploid plants, to reduce experimental variations/errors in ploidy level determination, we used diploid E. alatus as an internal standard. We mixed leaf tissues from triploid plants with those of diploid leaf tissues for nuclei isolation. If the nuclei mixture produced both a diploid peak and another peak that indicated 1.5 -fold more DNA per nucleus than that of the diploid peak, the triploid was confirmed. We further verified the ploidy of all triploid plants using a FACS Calibur Dual Laser Flow Cytometer and PI for DNA staining to confirm results. PI has its excitation wavelength at $488 \mathrm{~nm}$, and its emission wavelength at 562 to $588 \mathrm{~nm}$, whereas the excitation and emission wavelengths of DAPI for the Partec CyFlow Ploidy Analyser are distinctly different. DAPI has its excitation at $372 \mathrm{~nm}$ and emission at $456 \mathrm{~nm}$. Triploid plant lines were therefore further verified using two different DNA stains and two flow cytometers.

Based on 2025 immature and mature endosperm explants cultured in 2008 and 2009 , we obtained a total of 44 independently regenerated plant lines, 37 from immature endosperm explants and seven from the mature ones. Because of dormancy and cold treatment, eight of them did not grow well and eventually died. To identify triploids from the remaining 36 plant lines, we determined 
ploidy levels using the methods described previously and found that 28 plant lines had a DNA content per nucleus identical to that of diploid controls (Fig. 2A-C) and therefore concluded that they were diploids. However, we also identified eight independently regenerated triploid plants and the flow cytometry histograms for some of these triploid plants were shown in Figure 2D-F. When a diploid plant of E. alatus was used as an internal standard, that is, the diploid leaf tissues were mixed with leaf tissues from individual triploid plants for isolation of nuclei and then ploidy level determination, we observed a diploid
DNA peak and a triploid DNA peak in the same histogram. Peak values of DNA contents of the triploid nuclei were 1.5 times those of the diploid nuclei. Data from three representative triploid plants are shown in Figure 2G-I. The ploidy levels of all eight endospermderived triploid plants were determined and

Table 3. Comparison of in vitro plant regeneration efficiencies of immature, mature endosperm explants and immature embryos of Euonymus alatus 'Compactus'.

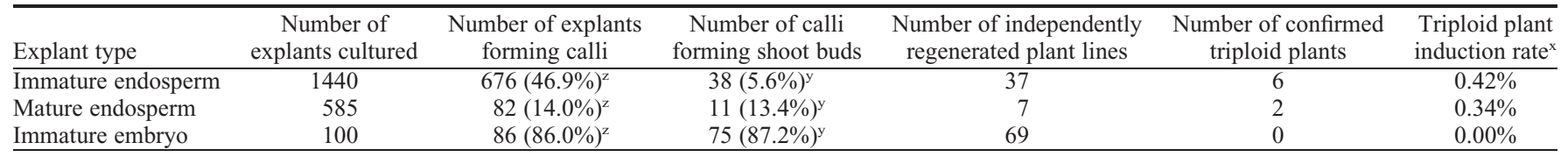

${ }^{2}$ Callus induction data were recorded at Week 12 of culture. Callus induction rates were calculated by dividing the number of explants forming calli by the number of embryo/endosperm explants cultured.

${ }^{y}$ Shoot bud induction data were recorded at Week 8 of culture. Shoot bud induction rates were calculated by dividing the number of calli showing shoot bud formation by the number of calli cultured.

${ }^{x}$ Triploid plant induction rates were calculated by dividing the number of independent triploid plants regenerated by the number of endosperm/embryo explants cultured.
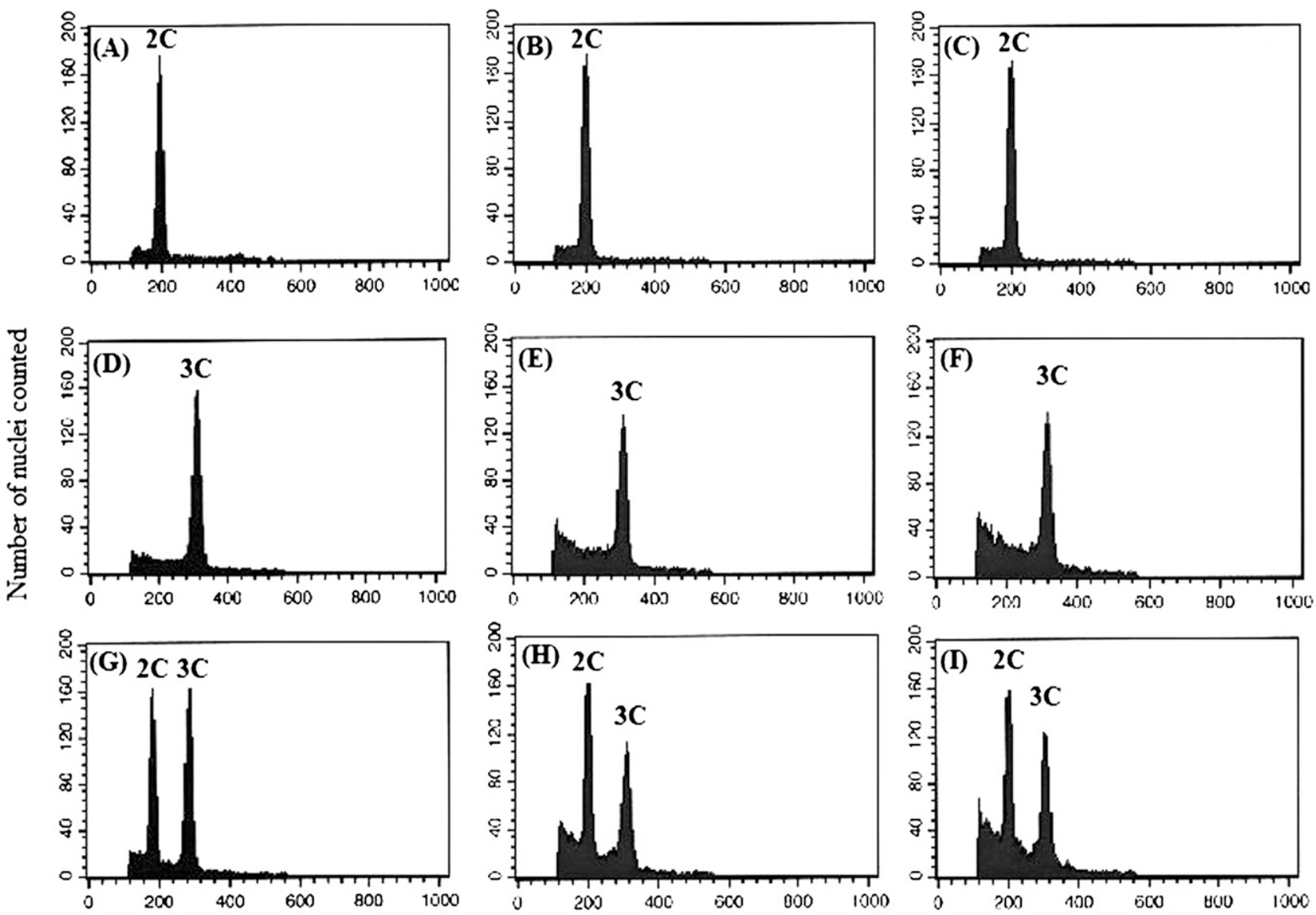

\section{Linear fluorescence intensity (DNA content per nucleus)}

Fig. 2. Flow cytometry histograms of Euonymus alatus 'Compactus' diploid plants and endosperm-derived plants. X-axis: linear fluorescence intensity (DNA content per nucleus), Y-axis: number of nuclei analyzed. (A) Histogram of linear fluorescence intensity of nuclei (the DNA content per nucleus) from a diploid (2C) plant having the peak value $\mathrm{z}^{\mathrm{z}}$ of 197; (B) histogram of linear fluorescence intensity of nuclei from a diploid (2C) plant that was derived from an embryonic callus tissue with the peak value of 200; (C) histogram of linear fluorescence intensity of nuclei from a plant derived from endosperm, with the peak value of 200, indicating it is a diploid plant; (D-F) histograms of linear fluorescence intensity of nuclei extracted from three endosperm-derived triploid (3C) plants, $\mathrm{T} 1, \mathrm{~T} 2$, and T3, with peak values of 307,310, and 310, respectively; (G-I) histograms of linear fluorescence intensity of mixtures of nuclei from a diploid plant and three triploid plants, respectively; (G) mixture of leaf tissues from a diploid plant and the triploid T1 plant with the peak values of 183 and 281; (H) mixture of leaf tissues from a diploid plant and the triploid T2 plant with peak values of 201 and 306; (I) mixture of leaf tissues from a diploid plant and the triploid T3 plant with peak values of 200 and 302. These data demonstrate that T1, T2, and T3 are triploids. ${ }^{2}$ The flow cytometer is basically a fluorescence particle counter, which measures fluorescence intensities in nuclei. The fluorescence intensity is proportional to the amount of the nuclear DNA to which the fluorescent stain is bound. A peak value of the fluorescence intensity reflects a mean of DNA content per nucleus. Peak values for the nuclear DNA contents from diploid plants of Euonymus alatus 'Compactus' were given the arbitrary value of $2 \mathrm{C}$ and therefore if the peak value of nuclear DNA content from an endosperm-derived Euonymus alatus 'Compactus' plant is 1.5-fold of that of the diploid's nuclear DNA content (2C), the plant was considered a triploid. 
verified three times using leaves harvested at different growth stages using two different ploidy analyzers and DNA staining dyes.

We also generated haploid plants from tobacco pollen and compared the ploidy levels of pollen-derived plants with diploid parental plants (data not shown). The results also indicate that the methods we used to determine the ploidy level of endosperm-derived plants were highly reliable. We therefore conclude that the eight plants of E. alatus derived from endosperm tissues are triploids.

Plant growth after transplantation. Triploid and diploid plants of E. alatus grew normally after transferring to the greenhouse and more than $85 \%$ of the plants survived and produced three to four pairs of new leaves (Fig. 1I). The survived plants stopped growing 4 months after transfer to the greenhouse and cold treatment was necessary to break bud dormancy and induce new growth. We have observed that so far, there are no visible differences in growth rate and morphology between the triploid and diploid plants.

\section{Discussion}

Since the first endosperm culture and regeneration protocol was reported in early 1950 s, attempts have been made to regenerate plants from endosperm tissues of a large number of plant species, but successful regeneration of buds/shoots from endosperm explants has been reported in 32 species only (Miyashita et al., 2009; Sun et al., 2011; Thomas and Chaturvedi, 2008). This suggests that plant regeneration from endosperm is difficult for many plant species. In general, it has been reported that one or more plant growth regulators are required for in vitro plant regeneration from immature endosperm. In most of the reports, callus induction media contained an auxin, preferably 2,4-D (reviewed by Thomas and Chaturvedi, 2008). In our study, we have observed that E. alatus 'Compactus' immature endosperm explants cultured on the MS medium supplemented with various concentrations of BA and 2,4-D had loose, yellowish, and friable calli. Green compact calli were formed on the MS medium supplemented with BA and NAA. Our data also show that, although $50 \%$ of immature endosperm explants could form calli, most of the endosperm-derived calli did not respond to different treatments of cytokinins (BA, zeatin, and kinetin) and auxins (IBA and IAA) and therefore failed to initiate buds. A small number of calli cultured on MS medium with 4.44 or $13.32 \mu \mathrm{M}$ BA and $0.49 \mu \mathrm{M}$ IBA produced buds, and the triploid plant regeneration rate was low, $0.42 \%$ (six triploid shoots regenerated from 1440 immature endosperm explants). By comparison, when mature endosperm explants were used as explants, both callus induction rate and triploid plant regeneration rate were much lower, $14 \%$ and $0.34 \%$, respectively. Similar results on shoot bud initiation were reported in Lonicera caerulea var. emphyllocalyx in which shoot primordia formation was observed on the MS media substituted only with $2.22 \mu \mathrm{M}$ BA plus
$0.49 \mu \mathrm{M}$ IBA $(10.0 \%)$ and $4.44 \mu \mathrm{M}$ BA plus $0.49 \mu \mathrm{M}$ or $4.92 \mu \mathrm{M}$ IBA $(3.3 \%$ and $2.7 \%$, respectively), (Miyashita et al., 2009). Slightly higher callus induction and shoot regeneration efficiencies were obtained if E. alatus 'Compactus' immature endosperm explants were used. Our observations demonstrate that it is difficult to regenerate plants from triploid tissues of E. alatus.

Plants derived from endosperm tissues of diploid plant species are not always all triploids (reviewed by Thomas and Chaturvedi, 2008). In this study, we observed that many endosperm-derived plants were diploid rather than triploid although most of the endosperm-derived calli were found to be triploid (data not shown). We have also observed that plant regeneration from diploid embryoderived callus tissues was more efficient than from the triploid endosperm tissues (Table 3). Diploid plants have also been regenerated from endosperm cultures in other plant species like Azadirachta indica (Chaturvedi et al., 2003) and Actinidia chinensis (Gui et al., 1993). Incomplete fertilization, chromosome loss, or development from maternal tissues have been proposed as possible reasons for the recovery of diploid plants from endosperm tissues (Gui et al., 1993). In Lonicera caerulea endosperm cultures, although most of the regenerated plants were hexaploid, an aneuploid plant has also been regenerated (Miyashita et al., 2009).

We have successfully produced triploid plants from both immature and mature endosperm explants of E. alatus using the protocol described in this article. We have obtained eight independently regenerated triploid plants based on our 2008 and 2009 studies. At the time of this manuscript submission, we have not observed any differences in plant morphology or growth and developmental patterns between the diploid plants and the endospermderived triploid plants. Further characterization of these plants, including field evaluation, will be important toward identification of the best sterile and non-invasive lines for commercialization. Non-invasive triploid E. alatus varieties are ideal candidates to replace the currently used, highly invasive counterparts, which should be beneficial to both the ornamental industry and the consumers.

\section{Literature Cited}

Chaturvedi, R., M.K. Razdan, and S.S. Bhojwani. 2003. An efficient protocol for the production of triploid plants from endosperm callus of neem, Azadirachta indica A. Juss. J. Plant Physiol. 160:557-564.

Chen, Y., L. Lu, W. Deng, X. Yang, R. McAvoy, D. Zhao, Y. Pei, K. Luo, H. Duan, W. Smith, C. Thammina, X. Zheng, D. Ellis, and Y. Li. 2006. In vitro regeneration and Agrobacterium-mediated genetic transformation of Euonymus alatus. Plant Cell Rep. 25:10431051.

Chen, Y., L. Lu, H. Duan, W. Deng, R. McAvoy, W. Smith, C. Thammina, S. von Bodman, Y. Li, D. Ye, and D. Zhao. 2008. Biotech approach to neutralize the invasiveness of burning bush (Euonymus alatus), a progress report on development of its genetic transformation system and functional analysis of sterile genes. Acta Hort. 769:21-29.

Clements, M.L. 2007. In vitro induction of polyploidy, rooting, and overcoming the dormancy limitations of Euonymus alatus 'Compactus'. MS thesis, Univ. of Conn., Storrs, CT. p. 536.

Ding, J., R. Reardon, Y. Wu, H. Zheng, and W. Fu. 2006. Biological control of invasive plants through collaboration between China and the United States of America: A perspective. Biol. Invasions 8:1439-1450.

Dirr, M.A. 1998. Manual of woody landscape plants. Stipes Publishing, Champaign, IL.

Gagliardi, J.A. and M.H. Brand. 2007. Connecticut nursery and landscape industry preferences for solutions to the sale and use of invasive plants. HortTechnology 17:39-45.

Gui, Y., S. Hong, S. Ke, and R.M. Skirvin. 1993. Fruit and vegetative characteristics of endospermderived kiwifruit (Actinidia chinensis F.) plant. Euphytica 71:57-62.

Heffernan, R. 2005. 15 Invasive plants of value to the green industry not yet banned in Connecticut. Conn. Green Industries Publishing, Botsford, CT.

Hong, S.M., Y. Li, and C.N. Stewart, Jr. 2009. Keeping the genie in the bottle: Transgene biocontainment by excision in pollen. Trends Biotechnol. 28:3-8.

Kang, B.-G., L. Osburn, D. Kopsell, G.A. Tuskan, and Z.-M. Cheng. 2009. Micropropagation of Populus trichocarpa 'Nisqually-1': The genotype deriving the Populus reference genome. Plant Cell Tissue Organ Cult. 99:251-257.

Kausch, A.P., J. Hague, M. Oliver, Y. Li, H. Daniell, P. Mascia, L.S. Watrud, and C.N. Stewart, Jr. 2010. Transgenic perennial biofuel feedstocks and strategies for bioconfinement. Biofuels 1:163-176.

Li, Y., Z. Cheng, W.A. Smith, D.R. Ellis, Y. Chen, X. Zheng, Y. Pei, K. Luo, D. Zhao, Q. Yao, H. Duan, and Q. Li. 2004. Invasive ornamental plants: Problems, challenges and molecular tools to neutralize their invasiveness. Crit. Rev. Plant Sci. 23:381-389.

Li, Y. and H. Duan. 2011. Molecular approaches for transgene containment and their potential applications in horticultural crops, p. 289-299. In: Mou, B. and R. Scorza (eds.). Transgenic horticultural crops: Challenges and opportunities. CRC Press, Boca Raton, FL.

Lloyd, G. and B. McCown. 1980. Commerciallyfeasible micro-propagation of mountain laurel, Kalmia latifolia, by use of shoot tip culture. Proc. Intl. Plant Prop. Soc. 30:421-427.

Luo, K., H. Duan, D. Zhao, X. Zheng, W. Deng, Y. Chen, C.N. Stewart, Jr., R. McAvoy, X. Jiang, Y. Wu, A. He, Y. Pei, and Y. Li. 2007. 'GMgene-deletor': Fused loxP-FRT recognition sequences dramatically improve the efficiency of FLP or CRE recombinase on transgene excision from pollen and seed of tobacco plants. Plant Biotechnol. J. 5:263-274.

Miyashita, T., T. Ohashi, F. Shibata, H. Araki, and Y. Hoshino. 2009. Plant regeneration with maintenance of the endosperm ploidy level by endosperm culture in Lonicera caerulea var. emphyllocalyx. Plant Cell Tissue Organ Cult. 98:291-301.

Murashige, T. and F. Skoog. 1962. A revised medium for rapid growth and bioassay with tobacco tissue cultures. Physiol. Plant. 15:473-497.

Nagy, J.K., S. Sule, and J.P. Sampaio. 2005. Apple tissue culture contamination by Rhodotorula spp.: Identification and prevention. In Vitro Cell. Dev. Biol. Plant 41:520-524.

Ramsey, J. and D.W. Schemske. 1998. Pathways, mechanisms, and rates of polyploidy formation 
in flowering plants. Annu. Rev. Ecol. Syst. 29:467-501

Sun, D.-Q., X.-H. Lu, G.-L. Liang, Q.-G. Guo, Y.-W. Mo, and J.-H. Xie. 2011. Production of triploid plants of papaya by endosperm culture. Plant Cell Tissue Organ Cult. 104:2329.

Thomas, T.D. and R. Chaturvedi. 2008. Endosperm culture: A novel method for triploid plant production. Plant Cell Tissue Organ Cult. 93:1-14.

U.S. Department of Agriculture. 2005a. Floriculture and nursery crops outlook. 25 Aug. 2006. $<$ http://www.ers.usda.gov/Publications/flo/Sep05/ FLO04.pdf $>$.

USDA. NRCS. 2005b. The PLANTS database, Version 3.5. Data compiled from various sources by Mark W. Skinner. National Plant Data
Center, Baton Rouge, LA. 15 July 2006. $<$ http://plants.usda.gov>.

Zheng, X., W. Deng, K. Luo, H. Duan, Y. Chen, R. McAvoy, S. Song, Y. Pei, and Y. Li. 2007. The cauliflower mosaic virus (CaMV) 35S promoter sequence alters the level and patterns of activity of adjacent tissue- and organspecific gene promoters. Plant Cell Rep. 26:11951203. 